J. Product. \& Dev., 22(3): 447-467(2017)

\title{
EFFECT OF CHICKEN MANURE AND Spirulina platensis ALGAE BIOFERTILIZER AS A PARTIAL REPLACEMENT OF INORGANIC NITROGEN IN BARHI DATE PALMS
}

\author{
M. A. El-Sayed'*; M. M.M. Al-Wasfy**and H. A.A. Boghdady * \\ * Hort. Department, Fac. of Agric., Minia University, Minia, Egypt. \\ **Hort. Department, Fac. of Agric., New Valley University, Qena, Egypt.
}

\section{ABSTRACT}

A field study was carried out during the years 2015 and 2016 on 25-year old Barhi date palm trees. Barhi date palms were uniform in vigour and received $N$ as 25 to 100\% mineral (inorganic) $N$ from ammonium nitrate $(33.5 \% \mathrm{~N}), 25$ to $100 \%$ organic nitrogen from chicken-manure $(2.5 \% \mathrm{~N})$ and the biofertilizer Spirulina platensis algae at 5 to $20 \mathrm{ml} /$ palm/ year as an attempt for partial replacement of mineral $N$ fertilizers in Barhi date palm orchards to promote yield and fruit quality and to protect our environment from pollution.

All growth characteristics, flowering and fruit setting aspects, weight and length of bunch, and yield/ palm were maximized due to supplying the palms with $N$ as $50 \%$ inorganic $N+50 \%$ organic manure + the biofertilizer Spirulina platensis algae at $10 \mathrm{ml} / \mathrm{palm} /$ year.

Leaf pigments and nutrients, as well as, both physical and chemical characteristics of the fruits were remarkably improved due to amending Barhi date palms with $N$ as $25 \%$ inorganic $N+75 \%$ chicken manure + the biofertilizer Spirulina platensis algae at $20 \mathrm{ml} / \mathrm{palm} / \mathrm{year}$.

The best results with regard to yield of Barhi date palms grown under Upper Egypt conditions were obtained due to supplying the palms with $N$ as 50\% inorganic $N+50 \%$ chicken manure + the biofertilizer Spirulina platensis algae at $10 \mathrm{ml} / \mathrm{palm} /$ year. Subjecting the palms with $N$ via $25 \%$ inorganic $N+75 \%$ chicken manure + the biofertilizer Spirulina platensis algae at $20 \mathrm{ml}$ palm / year gave the best results with regard to fruit quality.

Conclusively, it might be concluded that the application of $50 \%$ inorganic $N+50 \%$ chicken manure + the biofertilizer Spirulina platensis algae at $10 \mathrm{ml} / \mathrm{palm} /$ year of Barhi date palm may help in improving fruit physico-chemical quality and yield at harvest time under Upper Egypt conditions.

Keywords: Inorganic N, chicken manure, Spirulina platensis algae, Barhi date palms, growth, fruiting. 


\section{INTRODUCTION}

Many attempts were established for promoting the production and fruit quality of the prime and popular date palm $\mathrm{cv}$. Barhi by using unconventional methods. The excessive use of $\mathrm{N}$ via mineral $\mathrm{N}$ fertilizers lead to the promotion of vegetative growth characteristics at the expense of fruiting state. Therefore, controlling and adjusting the amount of $\mathrm{N}$ given to the palms was conducted by using organic manure and the biofertilizer Spirulina platensis algae. Organic manures have a pronounced stimulation on soil fertility, $\mathrm{N}$ fixation, organic matter, biosynthesis of natural hormones, vitamin $\mathrm{B}$, and antibiotics, root development the availability of most nutrients, water retention, Microbial activity and enzymes and have an obvious reduction on soil pH, salinity pathogens and erosion (Marschner, 1995; Wang et al., 2000, Venzon, et al., 2001, Bonanzinga et al., 2001 and Irizar- Garza et al., 2003).

Spirulina platensis algae biofertilizer is rich in polyunsaturated fatty acids linolenic acid, pigments namely phycocyanin, myxoxanthopathyl and zeaxunthin, proteins, amino acids namely leucine, isoleucine and valine, provitamin $\mathrm{A}$, vitamin $\mathrm{B}_{12}$ and carotenoids, chlorophylls and phycobiliprotein, selenium, sugars such as glucose, rhamnose, mannose, xylose, galactose and sulfated polysacharides and minerals namely $\mathrm{P}, \mathrm{Fe}, \mathrm{Co}$, $\mathrm{K}, \mathrm{Na}$ and Mg (Koru et al., 2008, Koru, 2009; Draman et al., 2009 and Henrikson, 2010).

The results of Al- Wasfy and El- Khawaga (2008), Ahmed et al., (2011), Al- Kahtani and Soliman, (2012), Abou- Baker, (2015), Omar (2015), Saied (2015) , El- Sayed et al., (2016) and Abdel- Wahab (2017) supported the benefits of using organic manures on fruiting of different date palm cvs.

Using the biofertilizer Spirulina platensis algae as a partial replacement of inorganic N was emphasized by the results of El- Khawaga (2011); AlySamar (2015) and Mohamed (2017). All of them confirmed the beneficial effect of such biofertilizer on fruiting of fruit crops.

The target of this study was elucidating the effect of using the organic fertilizer chicken-manure and the biofertilizer Spirulina platensis algae as a partial replacement of mineral $\mathrm{N}$ fertilizers on growth, palm nutritional status, yield and fruit quality of Barhi date palms grown under Upper Egypt conditions.

\section{MATERIALS AND METHODS}

This study was conducted in El- Mataana Experimental Res. Station orchards Hort. Research Institute, Agriculture Res. Center, Esna district Luxor governorate during the two consecutive seasons of 2015 and 2016, in 
which 24 tissue culture derived off shoots of Barhi date palms were selected for achieving this study. The palms were planted at $6 \times 7$ meters apart (100 palms / fed.). The texture of soil is silty clay.

The selected palms were at the same age and uniform in Vigor. These palms were 25 years old at the start of study, good physical conditions and free of insects, damages and diseases. The selected palms were irrigated through surface irrigation system. Pruning was performed to maintain leaf bunch ratio at 8:1. The number of female spathes per palm was adjusted to 10 spathes. Pollination was uniformly performed to avoid residues of metaxenia. Pollination was achieved by inserting five male strands into each female bunch using known high activity pollen source throughout 2-3 days after female spathe cracking. To prevent contamination of pollens, every bunch was bagged after inserting the male strands by paper bags which were tied at the ends using a piece of cotton for aeration. The bags were shaken lightly to ensure pollen distribution and were removed after four weeks (Dammas, 1998). Before carrying out hand pollination percentages of pollen stainability and pollen germination were determined according to Furr and Enriquez (1966) and Al- Tahir and Asif (1983).

Soil is classified as silty clay in texture with water table depth not less than two meters deep. The results of orchard soil analysis according to Wilde et al., (1985) are given in Table 1.

Each selected date palm received the common horticultural practices that are already applied in the orchard except those dealing with inorganic, organic and biofertilization of $\mathrm{N}$. Other horticultural practices such as irrigation, pruning and pest control management were carried out as usual.

Each palm tree was supplied with a total amount of $1000 \mathrm{~g}$ actual nitrogen (applied from inorganic or organic source alone, or in combinations). This experiment included the following eight treatments from mineral (inorganic) $\mathrm{N}$ (ammonium nitrate, $33.5 \% \mathrm{~N}$ ), chicken-manure $(2.5 \% \mathrm{~N})$ and Spirulina platensis algae arranged as follows:

1- $1000 \mathrm{~g}$ nitrogen as $100 \%$ inorganic $\mathrm{N}$ (2985.0 g ammonium nitrate) / palm/ year.

2- $75 \%$ inorganic $\mathrm{N}$ (750 g nitrogen from $2239 \mathrm{~g}$ ammonium nitrate)+ $25 \%$ organic $\mathrm{N}$ (250g nitrogen from 10kg chicken manure)/palm/ year.

3- 50\% inorganic $\mathrm{N}$ (500g nitrogen from 1493g ammonium nitrate) $+50 \%$ organic N (500 g nitrogen from $20 \mathrm{~kg}$ chicken manure /palm/year. 
Table (1): Mechanical, physical and chemical analysis of the tested orchard soil:

\begin{tabular}{|c|c|}
\hline Characters & Values \\
\hline \multicolumn{2}{|l|}{ Particle size distribution: } \\
\hline Sand \% & 10.60 \\
\hline Silt \% & 58.00 \\
\hline Clay \% & 31.40 \\
\hline Texture grade & Silty clay \\
\hline $\mathrm{pH}(1: 2.5$ extract $)$ & 8.00 \\
\hline E.C $(1: 2.5$ extract $\left.) / 25^{\circ} \mathrm{C}\right)\left(\mathrm{dsm}^{-1}\right)$ & 0.91 \\
\hline Organic matter \% & 2.09 \\
\hline $\mathrm{CaCO}_{3} \%$ & 1.22 \\
\hline \multicolumn{2}{|l|}{ Macronutrients values } \\
\hline Total N\% & 0.11 \\
\hline $\mathrm{P}(\mathrm{ppm}$, Olsen method) & 20.00 \\
\hline $\mathrm{K}$ (ppm, ammonium acetate) & 419.00 \\
\hline $\mathrm{Mg}(\mathrm{ppm})$ & 79.00 \\
\hline $\mathrm{S}(\mathrm{ppm})$ & 6.90 \\
\hline B(ppm hot water extractable) & 0.27 \\
\hline \multicolumn{2}{|l|}{ EDTA extractable micronutrients (ppm) } \\
\hline$\overline{\mathrm{Zn}}$ & 1.31 \\
\hline $\mathrm{Fe}$ & 11.00 \\
\hline $\mathrm{Mn}$ & 10.18 \\
\hline $\mathrm{Cu}$ & 1.60 \\
\hline
\end{tabular}

4- $25 \%$ inorganic $\mathrm{N}$ ( $250 \mathrm{~g}$ nitrogen from $747 \mathrm{~g}$ ammonium nitrate) $+75 \%$ organic $\mathrm{N}$ (750 g nitrogen from $30 \mathrm{~kg}$ chicken manure /palm/year.

5- $0.0 \%$ inorganic $\mathrm{N}+100 \%$ organic nitrogen (1000g nitrogen from $40 \mathrm{~kg}$ chicken manure /palm/year.

6- $75 \%$ inorganic $\mathrm{N}$ (750 g nitrogen from $2239 \mathrm{~g}$ ammonium nitrate $)+25 \%$ organic N (250 g nitrogen from $10 \mathrm{~kg}$ chicken manure $+5 \mathrm{ml}$ Spiraling platensis algae biofertilizer /palm/ year.

7- 50\% inorganic $\mathrm{N}$ (500g nitrogen from 1493g ammonium nitrate) $+50 \%$ organic N (500 g nitrogen from $20 \mathrm{~kg}$ chicken manure) + $10 \mathrm{ml}$ Spirolina platensis algae biofertilizer /palm/ year.

8- 25\% inorganic $\mathrm{N}$ ( $250 \mathrm{~g}$ nitrogen from $747 \mathrm{~g}$ ammonium nitrate $)+75 \%$ organic N (750 g nitrogen from $30 \mathrm{~kg}$ chicken manure) + $5 \mathrm{ml}$ Spiraling platensis algae biofertilizer /palm/ year. 
Ammonium nitrate $(33.5 \% \mathrm{~N})$ was added in three equal doses; in the first week of March, May and July for the two consecutive seasons. fertilizers $(2.5 \% \mathrm{~N})$ was added once at the first week of January during 2015 and 2016 seasons. Spirulina platensis algae biofertilizer at 5 to $20 \mathrm{ml} / \mathrm{palm} /$ year was also added once at the first week of March. Ammonium nitrate was distributed around the canopy of each palm while organic and biofertilizer were applied in holes $10 \mathrm{~cm}$ depth and $50 \mathrm{~cm}$ apart around the canopy of each palm. All the selected palms ( 24 palm) received $\mathrm{N}$ at fixed rate namely $1000 \mathrm{~g} \mathrm{~N} / \mathrm{palm} /$ year (Saied, 2015).

Analysis of chicken manure and Spirulina platensis algae biofertilizer are shown in Tables 2 and 3, respectively.

Table (2): Chemical analysis of chicken manure.

\begin{tabular}{|l|c|}
\hline Parameters & Values \\
\hline \hline OM. \% & 58.26 \\
\hline Organic carbon \% & 27.90 \\
\hline $\mathrm{pH}(11: 2.5$ extract $)$ & 6.5 \\
\hline E.C. $(1: 2.5$ extract $)\left(\mathrm{dsm}^{-1}\right)$ & 5.9 \\
\hline Total $\mathrm{N} \%$ & 2.5 \\
\hline Total $\mathrm{P} \%$ & 1.12 \\
\hline Total $\mathrm{K} \%$ & 1.21 \\
\hline Total $\mathrm{Fe}(\mathrm{ppm})$ & 18.5 \\
\hline Total $\mathrm{Zn}(\mathrm{ppm})$ & 43.22 \\
\hline
\end{tabular}

This experiment was arranged in a randomized complete block design (RCBD). Each treatment was replicated three times, one palm per each replicate.

During both seasons, the following parameters were recorded:

1- Pinnae and leaf length, width and area (Ahmed and Morsy, 1999). Number of pinnae and spines / leaf and spine length.

2- Leaf chlorophylls a, b and total and total carotenoids content (mg/ $1 \mathrm{~g}$ F.W.) (Von- Wettstein, 1957), leaf N, P, K and Mg percent (on dry weight basis (Summer, 1985 and Wilde et al., 1985). 
Table (3). Chemical analysis of Spirulina platensis, according to Koru et al. (2008).

\begin{tabular}{|l|c|}
\hline Parameters & Values \\
\hline \hline General composition $($ per $\mathbf{1 0 0} \mathbf{g}$ ) & \\
\hline Moisture & $3.5 \mathrm{~g}$. \\
\hline Protein & $63.5 \mathrm{~g}$. \\
\hline Fat ( Lipids) & $9.5 \mathrm{~g}$. \\
\hline Fibre & $3.00 \mathrm{~g}$. \\
\hline Ash & $6.70 \mathrm{~g}$. \\
\hline N- free extract & $15 . \mathrm{g}$. \\
\hline \hline Colorants & \\
\hline \hline Phycocyanin & $15.6 \mathrm{~g}$. \\
\hline Carotenoids & $456.00 \mathrm{mg}$. \\
\hline Chlorophyll- a & $1.30 \mathrm{~g}$. \\
\hline \hline Vitamins & \\
\hline \hline Provitamin A & $213.00 \mathrm{mg}$. \\
\hline Thiamin $\left(\mathrm{V} . \mathrm{B}_{1}\right)$ & $1.92 \mathrm{mg}$. \\
\hline Riboflavin $\left(\mathrm{V} . \mathrm{B}_{2}\right)$ & $3.44 \mathrm{mg}$. \\
\hline Vitamin $\mathrm{B}_{6}$ & $0.49 \mathrm{mg}$. \\
\hline Vitamin $\mathrm{B}_{12}$ & $0.12 \mathrm{mg}$. \\
\hline Vitamin E & $10.40 \mathrm{mg}$. \\
\hline Niacin & $11.30 \mathrm{mg}$. \\
\hline Folic acid & $40 \mathrm{mg}$. \\
\hline Panthothenic acid & $0.94 \mathrm{mg}$. \\
\hline Inositol & $76.00 \mathrm{mg}$. \\
\hline \hline Minerals & \\
\hline \hline Phosphorus & $916.00 \mathrm{mg}$. \\
\hline Iron & $53.60 \mathrm{mg}$. \\
\hline Calcium & $168 \mathrm{mg}$. \\
\hline Potassium & $1.83 \mathrm{~g}$. \\
\hline Sodium & $1.09 \mathrm{~g}$. \\
\hline Magnesium & $250 \mathrm{mg}$. \\
\hline
\end{tabular}

3- Number of strands/ spathe, number of flowers and fruits after fruit setting and just before harvesting per strand, initial fruit setting $\%$ and fruit retention $\%$.

4- Yield (kg/palm) as well as bunch weight $(\mathrm{g})$ and length $(\mathrm{cm})$. 
5- Average fruit weight $(\mathrm{g})$, length and diameter $(\mathrm{cm})$, percentages of seed and flesh weights, flesh / seed, fruit T.S.S., total, reducing and non reducing sugars, titratable acidity \% (A.O.A.C. 2000). Fruit total crude fiber, total soluble tannins \% (Balbaa, 1981) and flesh nitrite content (ppm) (Ridnour -Lisa et al., 2000).

Thereafter, the obtained data during the two seasons were collected, tabulated and subjected to the proper statistical analysis of variance method reported by Mead et al, (1993). The differences between treatment means were differentiated using new L.S.D at $5 \%$.

\section{RESULTS AND DISCUSSION}

\section{1- Vegetative growth characteristics:}

It can be stated from the obtained data in Tables (4 \& 5) that supplying Barhi date palms with N (1000 g N/ palm) through mineral N (ammonium nitrate, $33.5 \% \mathrm{~N}$ ) chicken-manure organic fertilizer ( $2.5 \%$ $\mathrm{N})$ and/ or Spirulina platensis algae biofertilizer significantly stimulated the growth characteristics (length, width and area of pinnae and leaf, number of pinnae / leaf , number of spines/ leaf and spine length) relative to using $\mathrm{N}$ as a $25 \%$ mineral $\mathrm{N}$ with chicken manure at $75 \%$ and/ or Spirulina platensis algae at $20 \mathrm{ml} / \mathrm{palm} /$ year, as well as, when $\mathrm{N}$ was added completely via mineral $\mathrm{N}$ or chicken manure. Enriching chicken manure when applied at 25 to $75 \%$ with Spirulina platensis algae significantly was superior using mineral $\mathrm{N}$ with organic manure alone in enhancing these growth aspects. The promotion on these growth traits was significantly depending on reducing the percentages of mineral $\mathrm{N}$ from 100 to $50 \%$ as well as increasing the percentages of chicken-manure from 0.0 to $50 \%$ and levels of Spirulina platensis algae from 5 to $10 \mathrm{ml}$. Using $\mathrm{N}$ as $100 \%$ mineral $\mathrm{N}$ significantly enhanced these growth characteristics than using $\mathrm{N}$ as $75 \%$ mineral with organic and biofertilizers at $75 \%$ and 20 $\mathrm{ml} / \mathrm{palm}$, respectively.

The largest values pinnae area $\left(69.24 \& 71.52 \mathrm{~cm}^{2}\right)$ and leaf area $\left(1.60,1.67 \mathrm{~m}^{2}\right)$ during both seasons, respectively were recorded on the palms that supplied with $\mathrm{N}$ as $50 \%$ mineral $\mathrm{N}+50 \%$ nitrogen form chicken manure+ Spirulina platensis algae at $10 \mathrm{ml} /$ palm. The lowest values of pinnae area $\left(48.31 \& 49.87 \mathrm{~cm}^{2}\right)$ and leaf area $\left(0.99 \& 1.04 \mathrm{~m}^{2}\right)$ during 2015 and 2016 seasons, respectively were observed on the palms that amended with $\mathrm{N}$ via $100 \%$ chicken manure alone. These results were true during both seasons. 


\section{2- Leaf pigments, $N, P, K$ and Mg content.}

It can be stated from the obtained data in Tables $(6 \& 7)$ that supplying Barhi date palms with $\mathrm{N}$ as 25 to $75 \%$ mineral $\mathrm{N}+25$ to $100 \%$ chicken manure organic fertilizer with or without the addition of Spirulina platensis algae biofertilizer at 5 to $20 \mathrm{ml}$ palm/ year significantly was favourable in enhancing leaf chlorophylls a, b and total, total carotenoids $\mathrm{N}, \mathrm{P}, \mathrm{K}$, and $\mathrm{Mg}$ in of Barhi date palms over the application of $\mathrm{N}$ as $100 \%$ inorganic $\mathrm{N}$. The stimulation in these pigments and nutrients significantly was related to reducing the percentages of inorganic $\mathrm{N}$, and at the same time icreasing the percentages of chicken manure from 0.0 to $100 \%$ and the levels of Spirulina platensis algae biofertilizer from 0.0 to $20 \mathrm{ml} /$ palm/ year. The maximum values of chlorophylls a $(4.59 \& 4.60 \mathrm{mg} / 1.0 \mathrm{~g}$ F.W.), b ( 1.80 \& $1.84 \mathrm{mg} / 1.0$ g F.W.), total chlorophylls ( $6.39 \& 6.44$ mg/ 1.0 g F.W.), total carotenoids (1.41 \& $1.39 \mathrm{mg} / 1.0$ g F.W.), N ( 1.96 $\& 1.97 \%), \mathrm{P}(0.191 \& 0.206 \%), \mathrm{K}(1.61 \& 1.66 \%)$ and $\mathrm{Mg}(1.02 \&$ $1.15 \%)$ were recorded on the palms that received $\mathrm{N}$ as $25 \%$ inorganic $+75 \%$ chicken manure+Spirulina platensis algae at $20 \mathrm{ml} / \mathrm{palm} /$ year, during both seasons, respectively. Supplying the palms with $\mathrm{N}$ as $100 \%$ inorganic $\mathrm{N}$ alone gave the minimum values. These results were true during both seasons.

\section{3- Flowering and fruit setting aspects.}

It is worth to mention from the data in Tables ( $8 \& 9$ ) that supplying Barhi date palms with 50 to $75 \%$ inorganic N plus 25 to $50 \%$ chicken manure and Spirulina platensis algae biofertilizer at 5 to $10 \mathrm{ml} /$ palm significantly was accompanied with enhancing number of strands/ spathe as well as number of flowers, and percentages of initial fruit setting and fruit retention relative to $100 \%$ organic or inorganic $\mathrm{N}$ as well as when added $25 \%$ mineral $\mathrm{N}$ even with the application of organic and biofertilizers. Reducing the percentages of mineral N from 50 to $25 \%$ with application of $75 \%$ organic fertilizer and Spirulina platensis at 20 $\mathrm{ml} /$ palm/year significantly reduced these flowering and setting aspects. Using the biofertilizer at 5 to $20 \mathrm{ml} / \mathrm{palm} / \mathrm{year}$ significantly enhanced the beneficial effects of using chicken manure on promoting such flowering and fruit setting characteristics relative to the chicken manure alone. Using $100 \%$ inorganic $\mathrm{N}$ was significantly preferable than using it completely via chicken manure in enhancing all flowering and fruit setting aspects. The maximum values of number of strands / spathe (26.0 \& 97.0), number of flowers / strand ( $117 \& 118$ flower), number of fruits / strand after 
berry setting ( $77.0 \& 81.0$ ), number of fruits / strand before harvesting (64.0 \& 67.0), initial fruit setting ( $65.9 \& 68.7 \%$ ) and fruit retention \% $(54.9 \& 56.9 \%)$ were recorded on the palms that received $\mathrm{N}$ as $50 \%$ inorganic $\mathrm{N}+50 \%$ chicken poultry manure + Spirulina platensis algae at $10 \mathrm{ml} / \mathrm{palm}$, during both seasons, respectively. The lowest values of flowering and fruit setting parameters were recorded on the palms that received $100 \%$ chicken poultry manure.

\section{4- Bunch weight and length and the yield per palm.}

It is obvious from the obtained data in Table (9) that subjecting date palms with 50 to $75 \%$ inorganic $\mathrm{N}+25$ to $50 \%$ chicken manure enriched or not with Spirulina platensis algae at 5 to $10 \mathrm{ml} /$ year significantly was preferable in improving bunch weight and length and yield / palm relative to application of $100 \%$ inorganic $\mathrm{N}$ or when added $25 \%$ inorganic $\mathrm{N}$ with chicken manure at $75 \%$ with or without the application of Spirulina platensis algae biofertilizer at $20 \mathrm{ml} / \mathrm{palm} /$ year.

The promotion was significantly related to the reduction in the percentages of inorganic $\mathrm{N}$ from 100 to $50 \%$ and at the same times increasing percentages of chicken manure from 0.0 to $50 \%$ and levels of Spirulina platensis algae from 0.0 to $10 \mathrm{ml} / \mathrm{palm}$. A significant reduction on bunch weight and length, as well as, yield/ palm was observed with reducing the percentages of inorganic $\mathrm{N}$ from 50 to $25 \%$ even with the application of organic and biofertilization. Using $\mathrm{N}$ completely via inorganic $\mathrm{N}$ was significantly superior than using it via $100 \%$ chicken manure in improving yield and bunch aspects. The heaviest bunches (18.3 \& $18.9 \mathrm{~kg}$ ) were borne on the palms that received $-50 \%$ inorganic +50 chicken manure + Spirulina platensis algae at $10 \mathrm{ml} /$ palm during both seasons,. Supplying date palms with $50 \%$ inorganic N $+50 \%$ chicken manure + Spirulina platensis algae biofertilizer at $10 \mathrm{ml} /$ palm / year gave the best results with regard to yield. Under such promised treatment, yield per palm reached $183.0 \& 189.0 \mathrm{~kg}$ per tree during 2015 and 2016 seasons respectively. The yield of the palms received $100 \%$ inorganic $\mathrm{N}$ and $100 \%$ chicken manure reached 143.0 and $116.0 \mathrm{~kg}$ in the first season and 149.0 and $121.0 \mathrm{~kg}$ in the second one, respectively.

\section{5- Fruit physical and chemical characteristics}

It is noticed from the obtained data in Tables (10 to 12) that varying $\mathrm{N}$ management had significant effect on both fruit physical and chemical characteristics. Amending the palms with 25 to $75 \%$ inorganic $\mathrm{N}+25$ to 
$100 \%$ chicken manure + Spirulina platensis algae biofertilizer at 5 to 20 $\mathrm{ml} /$ palm significantly was very effective in enhancing fruit quality in terms of increasing fruit weight and dimensions, flesh \%, flesh/ seed, T.S.S. $\%$ and total, reducing and non- reducing sugars and decreasing seed weight $\%$, titratable acidity $\%$, total crude fibre $\%$, total soluble tannins and nitrite content in the pulp over the application of $100 \%$ inorganic $\mathrm{N}$. The promotion on fruit quality was significantly associated with reducing inorganic $\mathrm{N}$ percentages from 100 to 0.0 and increasing percentages of chicken manure from 0.0 to $100 \%$ and levels of Spirulina platensis algae from 0.0 to $20 \mathrm{ml} / \mathrm{palm} /$ Using Spirulina platensis algae biofertilizer at 5 to $20 \mathrm{ml} /$ palm / year to chicken manure had significant promotion on both physical and chemical characteristics of the fruits over the application of mineral $\mathrm{N}$ with chicken-manure alone. The lowest values of fruit nitrite $(0.99 \& 0.94 \mathrm{ppm})$ were recorded due to using $25 \%$ mineral $\mathrm{N}+75 \%$ chicken manure + Spirulina platensis algae at $20 \mathrm{ml} /$ $\mathrm{palm} /$ year.

The best results with regard to fruit quality were obtained due to supplying the palms with $25 \%$ inorganic $\mathrm{N}+75 \%$ chicken + Spirulina platensis algae at $20 \mathrm{ml} / \mathrm{palm}$. Unfavorable effects on fruit quality were observed on the palms that subjected to $100 \%$ inorganic N. Similar trend was notice during 2015 \& 2016 seasons.

\section{DISCUSSION}

The beneficial effects of using chicken manure on growth and fruiting of Barhi date palms might be attributed to its essential roles on enhancing both soil physical and chemical characteristic- $\mathrm{N}$ fixation, organic matter, biosynthesis of natural hormones such as IAA, cytokines and $\mathrm{GA}_{3}, \mathrm{~B}$ vitamins and antibiotics, root development, availability of most nutrients, water retention, soil aggregation, soil exchange capacity and root development. Its action in reducing soil $\mathrm{pH}$, salinity and different soil pathogens did not neglect in this respect (Marschner, 1995; Wang et al., 2000, Bonanzinga et al., 2001, Venzon et al., 2001 and Irizar- Garza et al., 2003).

These results regarding the promoting effect of organic manures on growth, palm nutritional status, yield and fruit quality are in agreement with those obtained by Al- Wasfy and El- Khawaga (2008); Ahmed et al., (2011); Al- Kahtani and Soliman (2012); Abou - Baker (2015); Saied (2015) ; El- Sayed et al., (2016) and Abdel-Wahab (2017). 
The beneficial effects of the biofertilizer Spirulina platensis algae on growth, palm nutritional status, yield and fruit quality might be attributed to its higher content from proteins, fats, lipids, polynsaturate fatty acids linolenic acid, pigments namely phycocyanin, myxoxanthopathy \& and zeoxanthin, corotenoids; chlorophylls a, vitamins namely provitamin A, thiamin $\left(\mathrm{B}_{1}\right)$, Riboflavin $\left(\mathrm{B}_{2}\right), \mathrm{B}_{6} \& \mathrm{~B}_{12}, \mathrm{E}$, nacin, folic acid, panthothenic acid and inositol and minerals such as $\mathrm{P}, \mathrm{Fe}, \mathrm{Ca}, \mathrm{K}, \mathrm{Na}$, and $\mathrm{Mg}$. These chemical components of Spirulina platensis algae from antioxidants surely reflected on protecting the plant cells from aging as well as presenting the formation of reactive oxygen species (ROS) that arte responsible for destroying plant cells. The occurrence of higher levels of nutrients in such blue algae was reflected on enhancing cell divbision and the biosynthesis of most organic foods (Koru et al., (2008) Koru, (2009); Draman, (2010) and Henrikson, 2010).

These results regarding the beneficial effects of using the biofertilizer Spirulina platensis algae as a partial replacement of mineral N fertilizers on fruiting of Barhi date palms are in concordance with those obtained by El- Khawaga (2011); Aly- Samar (2015) and Mohamed (2017).

Conclusively, it might be concluded that the application of $50 \%$ inorganic N $+50 \%$ chicken manure + the biofertilizer Spirulina platensis algae at $10 \mathrm{ml} / \mathrm{palm} /$ year of Barhi date palm may help in improving fruit physicochemical quality and yield at harvest time under Upper Egypt conditions.

\section{REFERENCES}

Abdel- Wahab, A.Kh.M. (2017): Influence of replacement apart of inorganic nitrogen fertilizers by using humic acid and E.M. on fruiting of Sewy date palms. M. Sc. Thesis Fac. of Agric. Minia Univ. Egypt.

Abou- Baker, A.H.A. (2015): Effect of replacement of inorganic $\mathrm{N}$ fertilizer partially by using organic and biofertilization on productivity of Sakkoti date palms. M. Sc. Thesis Fac. of Agric. Minia Univ.

Ahmed, F. F. and Morsy, M. H. (1999): A new method for measuring, leaf area in different fruit crops. Minia J. of Agric. Res. \& Develop., (19): 97-105.

Ahmed, F.F.; Akl, A.M.; El- Mamlouk, E.A.H. and Mohamed, H.H. (2011): Reducing inorganic $N$ fertilizers partially in Sakkoti date palm orchards by application of organic and biofertilization. Minia J. of Agric. Res. \& Develop., 31(2): 189-203. 
Al- Kahtani, S.H. and Soliman, S.S. (2012): Effects of organic manures on yield, fruit quality, $m$ nutrients and heavy metals content of Barhi date palm cultivar. African J. of Biotech. , 11(65): 12818-12824.

Aly- Samar, S.H. (2015): Influence of reducing mineral fertilizer partially by using plant compost enriched with Spirulina platensis Algae on fruiting of Flame seedless grapevines. M. Sc. Thesis Fac. of Agric. Minia Univ. Egypt.

Al-Tahir, O.A. and Asif, M.I. (1983): Study of variation and date pollen material. Proc. of the $1^{\text {th }}$ Symp. On the Date Palm in Saudi Arabia, King Faissal Univ. pp. 62-66.

Al- Wasfy, M.M. and El- Khawaga, A.S. (2008): Effect of organic fertilization on growth, yield and fruit quality of Zaghloul date palm grown in sandy Soil. Assiut J. of Agric. Sci., 39(1):121-133.

A.O.A.C. (2000): Association of Official Agricultural Chemists. Official Methods of Analysis $14^{\text {th }}$ ed. (A. O. A. C.) Benjamin Franklin Station, Washington D. E. U.S.A., pp. $490-510$.

Balbaa, S. I. (1981): Chemistry of Drugs. Laboratory Manual. Cairo Univ., Chapter 6: 127-132.

Bonanzinga, M.; Martellucci, R. and Nardi, G. (2001): The organic viticulure sector in Tuscany(Bibliography citation). Informatory Agrario , 57: 31, 71-72 CAB Abstracts.

Dammas, M. O. (1998): Fruit growth and receptivity of pistillate flowers pollination in two date palm cultivars (Phoenix dactylifera L.). M. Sc. Thesis, Fac. of Meteorology, Environment and Arid land Agric. King Abdel Aziz Univ., pp. 50 - 57.

Draman, H.; Koru, E. and Dibekliolgu, H. (2009): Fatty acid profile of Spirulina platensis used as a food supplement. Israli Journal of Aquaculture-Bamideh, 61(2): 134-142.

El- Khawaga, A.S. (2011): Partial replacement of mineral $\mathrm{N}$ fertilizers by using humic acid and Spirulina platensis algae biofertilizer in Florida Prince peach orchards. Middle East J. Appl. Sci., 1: 5-10.

El- Sayed, M.A.H.; Aly, A.H. and Abdel -Wahab, A. Kh. M. (2016): Effect of using humic acid and effective microorganisms as a partial replacement of mineral nitrogen fertilizer on fruiting of Sewy date palms. J. Biol. Chem. Environ. Sci. , 11(3): 60-85.

Furr, R. and Enriquez, V. M. (1966): Germination of date pollen in culture media. Rept Ann. Date cvs Inst., 45:24- 27. 
Henrikson, R. (2010): Spirulina World food, how this micro algae can transform your health and our planet, published by Ronore Enterprises, Inc. Po. Box Gog. Hana. Maui, Hawaii 96718 USA, ISBN 1453766987 , pp. 195.

Irizar-Garza, M. B. Vargaqzuez, P.; Garza, Garcia, D.; Tuty Cough, C.; Rojas martinet, I.; Trujillo Compos, A, Garcia Silva, R.; Aguirre Montoya, D.; Martinez Gonzalez, J. C.; Alvarado Mendoza, S.; Grageda Cabrera, O.; Valero Garza, I and Aguirre Medina, J. F. (2003): Use of bio- fertilizers in agricultural crops in the central region of mexico. Agriculture Teecnica en Mexico Institute Nacional de Investigaciones Forestale-4-Agricolas y pecuarias (INIFAP), Mexico City Mexico, 29: 2, 213-225.

Koru, E. (2009): Spirulina micro algae production and breeding in commercial. Turkey Journal of Agriculture, May June 2008, Issue: 11, (3): 133- 134.

Koru, E.; Cirik, S. and Turan, G. (2008): The use of Spirulina for feed production in Turkey University- industry co- operation project (USIGEM) project investigator and consultant Eids Koru, pp. 100, Bornova- Izmir/Turkey.

Marschner, H. (1995): Mineral Nutrition of Higher Plants. Academic Press. (London).

Mead, R.; Currnow, R.N. and Harted, A.M. (1993): Methods in Agricultural and Experimental and Biology. $2^{\text {nd }}$ Ed Hall, London pp. 10-44.

Mohamed, I.A. (2017): Effect of reducing mineral $\mathrm{N}$ fertilization partially by using plant compost enriched with Spirulina platensis on Fruiting of Ewaise mango trees. M. Sc. Thesis Fac. of Agric. Minia Univ. Egypt.

Omar, M. G.G. (2015): Response of Saidy date palms growing under new Valley conditions to some organic, inorganic and biofertilization as well as some antioxidant treatments Ph. D. thesis, Fac. of Agric. Minia Univ. Egypt.

Ridnour- Lisa, A.; Sim- Juliu, E.; Michael, A.H. David, A.W.; Sean, M.M.; Carry, R.B. and Douglas, R.S. (2000): A spectrophotometric methods for the direct detection and Quantitation of nitrite oxide, nitrite and nitrate in cell culture Media. Analytical Biochemistry, 281: 233- 229.

Saied, H.H.M. (2015): Influence of replacing inorganic N fertilizer partially in Sakkoti date palm orchards by using some natural organic and biostimulants. Ph. D. Thesis Fac. of Agric. Minia Univ., Egypt.

Summer, M.E. (1985): Diagnosis and recommendation Integrated system (DRIS) as a guide to orchard fertilization. Hort. Abst., 55(8): 7502. 
Venzon, M.; Pallini, A. and Amaral, D. S. S. L. (2001): Strategies of environmental pest management. (Agriculture Organica) [Portuguese]. Informe Agropecuario Empresa de Pesquisa Agropecuaria de Minas Gerais Belo Horizonte, Brazil: 22:212: 19-28.

Von- Wettstein, D.V. (1957): Chlorophyll- Ithale under submikrosphpische formiuechrel der plastiden celi, Drp. Trop./ Res. Amer. Soc. Hort. Sci. (20): 427-433.

Wang, C. Q.; Wang, S. L.; Zhoiu, J. Y.; Zhou, Q. Y.; Deng, Z. Y. and Han, W. C. (2000): On the citrus requirement on nutrition and the special organic compound fertilizers. South China Fruits, 29 (5): 18-22.

Wilde, S. A.; Corey, R. B.; Lyer, I. G. and Voigt, G. K. (1985): Soil and Plant Analysis for Tree Culture. Oxford \& IBH publishing Co., New Delhi, pp. 1 - 218.

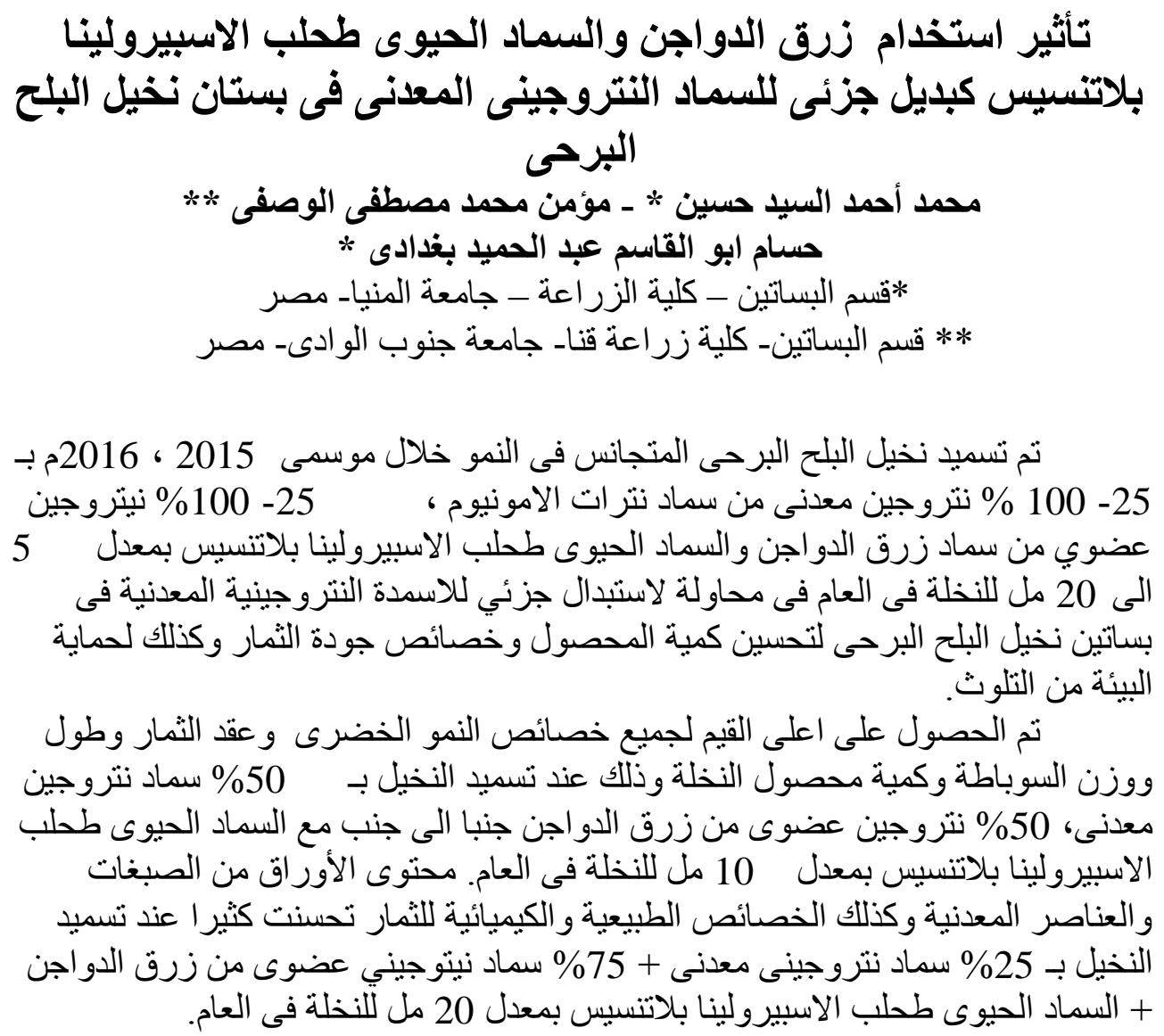




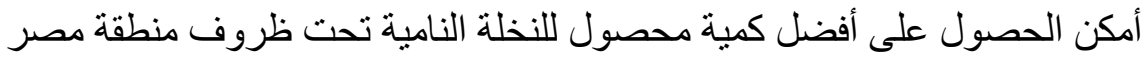

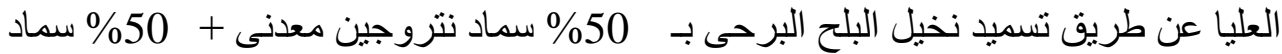

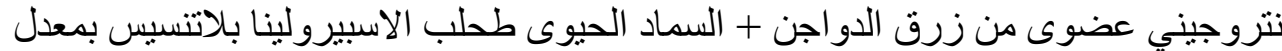

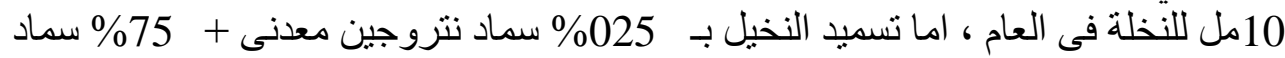

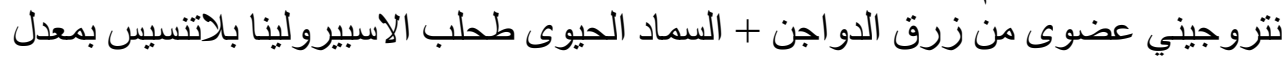

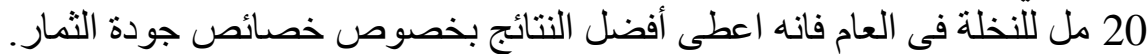

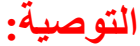

الكلمات الدالة : النتروجين الغير عضوى - سماد زرق الدواجن ، طحلب الاسبيرولينا بلاتنسيس - نخيل البلح البرحى- النمو و الاثمار. 
EL-SAYED et al. 